\title{
Zakrzepowa plamica małopłytkowa u chorej na toczeń rumieniowaty układowy - powikłanie układowej choroby tkanki tącznej czy zespót nakładania?
}

\section{Thrombotic thrombocytopenic purpura in a patient with systemic lupus erythematosus - complication of connective tissue disease or overlap syndrome?}

\author{
Dominika Grzegowska', Anna Masiak', Zenobia Czuszyńska¹, Marcin Ziętkiewicz¹, Wojciech Homenda², \\ Michalina Pejska², Zbigniew Zdrojewski
}

${ }^{1}$ Katedra i Klinika Chorób Wewnętrznych, Chorób Tkanki Łącznej i Geriatrii Gdańskiego Uniwersytetu Medycznego ul. Dębinki 7, 80-211 Gdańsk

Kierownik: prof. dr hab. n. med. Zbigniew Zdrojewski

${ }^{2}$ Oddział Chorób Wewnętrznych i Hematologiczny Wojewódzkiego Szpitala Specjalistycznego w Słupsku

ul. Hubalczyków 1, 76-200 Słupsk

Ordynator: dr n. med. Wojciech Homenda

\section{SUMMARY}

Thrombotic thrombocytopenic purpura (TTP) and systemic lupus erythematosus (SLE) are two separate diseases, whose clinical symptoms may be similar. The coexistence of these two diseases is very rare. We present the case report of a 29-year-old female patient with simultaneous diagnosis of TTP and SLE. The

\section{STRESZCZENIE}

Zakrzepowa plamica małopły tkowa (TTP) i toczeń rumieniowaty układowy (SLE) to dwie odrębne jednostki chorobowe, których objawy kliniczne mogą być podobne. Współistnienie tych chorób jest bardzo rzadkie. Przedstawiono przypadek 29-letniej chorej, u której jednocześnie rozpoznano TTP i SLE. Celem pracy purpose of this article is to draw attention to the diagnostic difficulties which may result from the co-existence of both diseases. Key words: thrombotic thrombocytopenic purpura, systemic lupus erythematosus, metalloproteinase ADAMTS13, thrombotic microangiopathy, overlap syndrome, plasma exchange (PEX).

było zwrócenie uwagi na trudności diagnostyczne, jakie może sprawić współwystępowanie obu schorzeń.

Słowa kluczowe: zakrzepowa plamica małopłytkowa, toczeń rumieniowaty układowy, metaloproteinaza ADAMTS13, mikroangiopatia zakrzepowa, zespół nakładania, plazmafereza.

\section{WSTĘP}

Toczeń rumieniowaty układowy (systemic lupus erythematosus - SLE) jest schorzeniem autoimmunologicznym o bogatej symptomatologii. Zakrzepowa plamica małopłytkowa (thrombotic thrombocytopenic purpura - TTP) jest rzadko występującym zespołem o równie zróżnicowanych objawach klinicznych. Współwystępowanie obu tych schorzeń jest sporadyczne, jednak obarczone potencjalnie wysokim ryzykiem zgonu. Wczesna diagnoza i właściwa terapia znacznie poprawiają rokowanie. Obraz kliniczny obu schorzeń może być podobny, dlatego diagnostyka różnicowa oparta wyłącznie na prezentowanych objawach jest bardzo trudna, a w niektórych sytuacjach wręcz niemożliwa.

Celem pracy było zwrócenie uwagi na trudności diagnostyczne w przypadku współwystępowania TTP i SLE.

\section{OPIS PRZYPADKU}

29-letnia pacjentka została przyjęta w trybie pilnym na Oddział Chorób Wewnętrznych i Hematologii Wojewódzkiego Szpitala

Specjalistycznego w Słupsku po dwukrotnym incydencie omdlenia, poprzedzonym bólami głowy i wymiotami treścią pokarmową. Powtarzające się omdlenia, których etiologii nie ustalono, nawracały u chorej od okresu dzieciństwa. Dodatkowo od kilku lat występowały bóle głowy, objaw Raynauda, wypadanie włosów oraz nadwrażliwość na światło słoneczne pod postacią zmian grudkowo-plamistych. Od kilku miesięcy występowało również poranne krwioplucie, jednak chora nie zgłosiła się z tego powodu do lekarza. Przed hospitalizacją nie przyjmowała na stałe żadnych leków i nigdy nie była w ciąży. Matka pacjentki chorowała na reumatoidalne zapalenie stawów.

Przy przyjęciu do szpitala pacjentka była w stanie ogólnym dość dobrym, wydolna krążeniowo i oddechowo, bez gorączki. W badaniu przedmiotowym występowały zmiany skórne o charakterze plamisto-grudkowym odpowiadające toczniowej osutce z fotonadwrażliwości, wybroczyny na stopach i dłoniach, limfadenopatia (powiększone węzły chłonne szyjne, nadobojczykowe oraz w lewym dole pachowym) i niewielka tkliwość w nadbrzuszu. W morfologii krwi obwodowej 
zwracały uwagę niedokrwistość normocytarna, limfopenia oraz znaczna małopłytkowość, pogłębiające się w czasie kolejnych godzin hospitalizacji. Stwierdzano również cechy hemolizy, podwyższone stężenie produktów degradacji fibryny, umiarkowanie podwyższone parametry stanu zapalnego, białkomocz nerczycowy (dobowa utrata białka 3,9 g), a w gazometrii krwi włośniczkowej - hipoksemię z hipokapnią. Nie odnotowano cech aktywności osadu moczu ani upośledzenia funkcji nerek. Badania laboratoryjne zestawiono w tabeli 1.

Ze względu na stan po omdleniu wykonano tomografię komputerową głowy, w której nie stwierdzono istotnych patologii.
Biorąc pod uwagę hipoksemię oraz krwioplucie, wykonano również badanie angio-TK tętnic płucnych, nie uwidoczniając cech zatorowości płucnej, natomiast w obu polach płucnych zobrazowano liczne rozsiane zgęszczenia drobnoguzkowe $\mathrm{z}$ tendencją do zlewania się, sugerujące zmiany o charakterze zapalnym. Wykonano szereg badań mikrobiologicznych, serologicznych i molekularnych, na podstawie których wykluczono najczęstsze czynniki infekcyjne mogące być przyczyną obserwowanych zmian. Wobec pogłębiających się zaburzeń hematologicznych wykonano rozmaz krwi obwodowej, w którym stwierdzono 18\% schistocytów. Rozpoznano mikroangiopatię

TABELA 1. Wyniki badań laboratoryjnych z początkowego okresu hospitalizacji

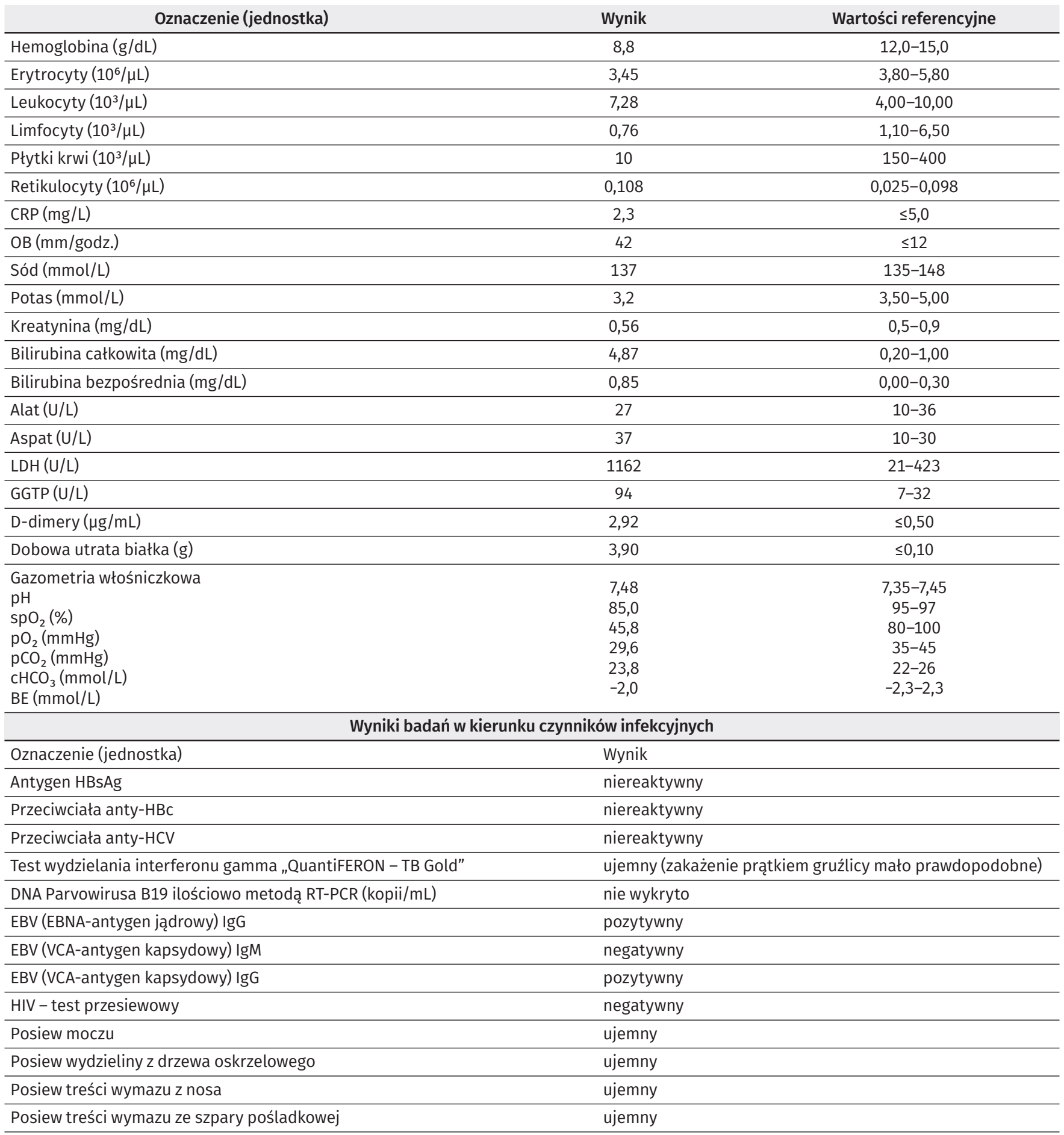


TABELA 2. Wyniki badań immunologicznych wyjściowe i po leczeniu immunosupresyjnym

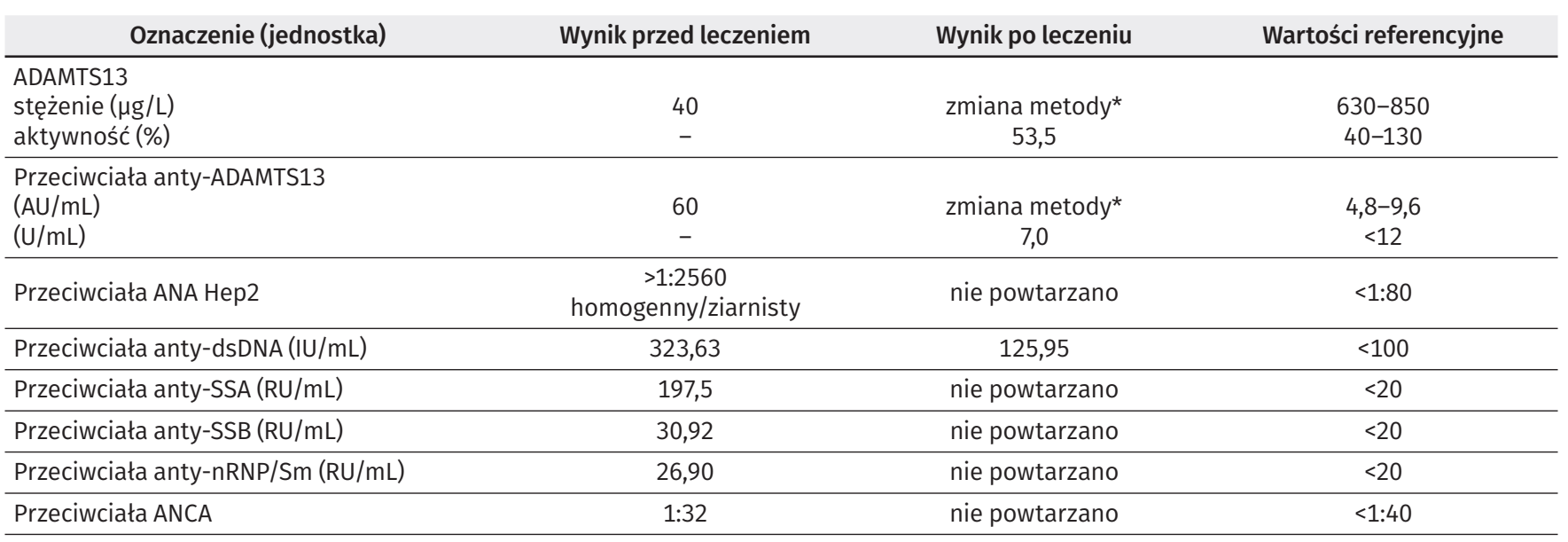

* zmiana metod oznaczania przez Centralne Laboratorium Kliniczne - wyniki stężenia/aktywności ADAMTS13 oraz stężenia przeciwciał anty-ADAMTS13 przed leczeniem i po leczeniu można analizować jedynie w oparciu o podane normy referencyjne i nie można ich ze sobą porównywać

zakrzepową oraz wysunięto podejrzenie zakrzepowej plamicy małopłytkowej. Rozpoznanie ostrej nabytej postaci TTP potwierdzono w oparciu o stwierdzenie niskiej aktywności metaloproteinazy ADAMTS13 oraz obecności autoprzeciwciał skierowanych przeciwko temu enzymowi. Jednocześnie wobec podejrzenia choroby układowej wykonano oznaczenia autoprzeciwciał, stwierdzając obecność przeciwciał przeciwjądrowych, przeciwko dwuniciowemu DNA, przeciwko SSA, SSB i RNP/Sm (tab. 2).

Biorąc pod uwagę obraz kliniczny i wyniki badań immunologicznych, rozpoznano SLE w oparciu o kryteria wg SLICC: ostry toczeń skórny z manifestacją zmian plamisto-grudkowych, wypadanie włosów, limfopenia $<1,0$ G/L, miano przeciwciał przeciwjądrowych powyżej wartości referencyjnych oznaczonych metodą immunofluorescencji pośredniej (IF) oraz stężenie przeciwciał anty-dsDNA dwukrotnie powyżej wartości referencyjnych oznaczonych metodą immunoenzymatyczną (ELISA). Całość obrazu klinicznego przemawiała za rozpoznaniem TTP w przebiegu choroby układowej, w związku z czym rozpoczęto intensywne leczenie immunosupresyjne (metyloprednizolon w pulsach dożylnych 500 mg przez 3 kolejne dni z następczą terapią prednizonem $1 \mathrm{mg} / \mathrm{kg} \mathrm{mc} / \mathrm{d}$, cyklofosfamid 1,0 g we wlewie dożylnym w drugim dniu sterydoterapii), jednocześnie ustalano termin rozpoczęcia terapii plazmaferezami.

W piątej dobie hospitalizacji, pomimo wdrożonego leczenia immunosupresyjnego, stan chorej zaczął się pogarszać nasilało się krwioplucie, wystąpiły zaburzenia świadomości, a w badaniach laboratoryjnych obserwowano postępującą niedokrwistość. W związku z pogłębianiem się ostrej niewydolności oddechowej w przebiegu krwawienia do pęcherzyków płucnych pacjentkę w stanie ciężkim przeniesiono na oddział intensywnej terapii, gdzie prowadzono respiratoroterapię. Rozpoczęto również zabiegi terapeutycznej wymiany osocza (5 zabiegów plazmaferezy, 3000 mL wymiany osocza na zabieg). Stan chorej uległ spektakularnej poprawie. W badaniach laboratoryjnych obserwowano redukcję wykładników hemolizy oraz zmniejszenie odsetka schistocytów do 1,8\%. Po wyrównaniu stanu ogólnego chorą przekazano do Kliniki Chorób
Wewnętrznych, Chorób Tkanki Łącznej i Geriatrii Uniwersyteckiego Centrum Klinicznego w Gdańsku, gdzie kontynuowano leczenie immunosupresyjne (cyklofosfamid w pulsach po 1,0 g co 21 dni do łącznej dawki 3,0 g). Po uzyskaniu remisji w leczeniu podtrzymującym zastosowano mykofenolan mofetylu (MMF) w dawce $2 \times 750 \mathrm{mg}$ łącznie z prednizonem w stopniowo redukowanej dawce.

Po 2 miesiącach od rozpoczęcia leczenia dokonano oceny wykładników immunologicznych TTP i SLE, stwierdzając normalizację aktywności ADAMTS13, obniżenie poziomu przeciwciał anty-ADAMTS13 oraz przeciwciał przeciwko dwuniciowemu DNA. Nie zaobserwowano białkomoczu. Nie stwierdzono również obecności przeciwciał antyfosfolipidowych, aczkolwiek przeciwciała te nie zostały oznaczone przed rozpoczęciem leczenia z uwagi na ujemny wywiad zakrzepowo-zatorowy, niepowikłany wywiad położniczy oraz brak typowych cech koagulopatii w badaniach laboratoryjnych przy przyjęciu. Pacjentka pozostaje pod stałą opieką poradni przyklinicznej. W leczeniu stosowano MMF $(2 \times 750 \mathrm{mg})$, hydroksychlorochinę (200 mg) oraz prednizon w dawkach stopniowo redukowanych. Po 6 miesiącach terapii rozpoczęto redukcję dawki MMF $(2 \times 500 \mathrm{mg})$. Od tego czasu obserwuje się skłonność do leukopenii, neutropenii, obniżenie składowej C3 dopełniacza, wypadanie włosów i ogólne osłabienie. Zdecydowano o podaniu pulsów steroidowych, zwiększeniu dawki steroidów oraz zastąpieniu MMF azatiopryną $(2 \times 50 \mathrm{mg})$. Uzyskano poprawę parametrów krwi i stanu klinicznego. Utrzymuje się nadal podwyższony poziom przeciwciał anty-dsDNA.

\section{DYSKUSJA}

Zakrzepowa plamica małopłytkowa, znana również jako zespół Moschcowitza [1], jest rzadkim, potencjalnie zagrażającym życiu zespołem chorobowym. Zasadniczą rolę w jej patogenezie odgrywa wrodzony lub nabyty niedobór osoczowej metaloproteinazy ADAMTS13 (A disintegrin and metalloproteinase with a thrombospondin type 1 motif, member 13 - von Willebrand factor cleaving protein), odpowiedzialnej za degradację „niezwykle 
wielkich" multimerów czynnika von Willebranda (Ultra-large multimers of $v W F$ ] [2]. W przypadku niedoboru ADAMTS13 dochodzi do powstawania agregatów płytkowych w świetle naczyń krwionośnych, czego konsekwencją jest małopłytkowość „ze zużycia” oraz niedokrwistość hemolityczna wynikająca z mechanicznego uszkadzania erytrocytów w procesie wykrzepiania śródnaczyniowego [3]. Mikroangiopatia przyczynia się do powstawania zaburzeń zakrzepowo-zatorowych o wielonarządowych objawach (najczęściej ze strony centralnego układu nerwowego i nerek, rzadziej z układu sercowo-naczyniowego i pokarmowego).

Klasyczne rozpoznanie TTP opierało się na współwystępowaniu pięciu objawów: małopłytkowości, mikroangiopatycznej niedokrwistości hemolitycznej, gorączki, objawów z centralnego układu nerwowego i niewydolności nerek [4]. Obecnie ze względu na bardzo rzadkie występowanie pełnoobjawowego zespołu, a także z powodu wysokiej śmiertelności w przypadku opóźnienia leczenia kliniczne rozpoznanie TTP należy postawić w przypadku stwierdzenia dwóch pierwszych objawów, tj. małopłytkowości i mikroangiopatycznej niedokrwistości hemolitycznej, jeśli nie można ich wytłumaczyć inną przyczyną. W celu potwierdzenia rozpoznania TTP należy wykonać oznaczenia aktywności ADAMTS13 oraz obecności autoprzeciwciał anty-ADAMTS13 (w postaci nabytej). Trzeba jednak z całą mocą podkreślić, iż diagnostyka powinna być prowadzona równolegle $\mathrm{z}$ intensy wnym leczeniem, które powinno się rozpocząć w przeciągu 4-8 godz. od momentu wystąpienia pierwszych objawów sugerujących TTP [5].

Toczeń jest układowym schorzeniem tkanki łącznej o etiologii autoimmunologicznej. Charakteryzuje się przewlekłym stanem zapalnym, obecnością przeciwciał przeciwjądrowych i różnorodną manifestacją kliniczną z zajęciem wielu narządów (m.in. nerek, skóry i układu nerwowego) oraz typowymi zmianami hematologicznymi. Obecnie chorobę rozpoznaje się w oparciu o kryteria grupy SLICC (systemic lupus international collaborating clinics) zaproponowane w 2012 r. [6].

Nie jest znana dokładna częstość współwystępowania TTP i układowych chorób tkanki łącznej. Dotychczas na świecie opublikowano kilkadziesiąt opisów przypadków TTP u chorych na SLE [7], a częstość ich współistnienia ocenia się na ok. 0,5\% [8]. Zakrzepowa plamica małopłytkowa na ogół rozwija się u chorych z wieloletnim rozpoznaniem tocznia, najczęściej w okresie jego dużej aktywności, z zajęciem nerek [9]. Zakrzepowa plamica małopłytkowa jako pierwsza manifestacja tocznia jest wyjątkowo rzadko spotykana, a jednocześnie cechuje się wysoką śmiertelnością. Patomechanizm nie został do końca wyjaśniony [10]. Obecnie przypuszcza się, że u podstaw reakcji autoimmunologicznej, w wyniku której rozwija się nabyta TTP, mogą brać udział takie same czynniki, jak w przypadku innych chorób układowych [11]. Bierze się pod uwagę przede wszystkim predyspozycję genetyczną i dysfunkcję układu odpornościowego [12, 13], która ujawnia się zwykle po zadziałaniu czynnika indukującego nieprawidłową reakcję immunologiczną (np. infekcja) [14]. Współwystępowanie TTP i kolagenozy można rozpatrywać w kategoriach zespołu nakładania (overlap syndrome) dwóch chorób autoimmunologicznych o podobnej manifestacji klinicznej i być może zbliżonym patomechanizmie [15]. Nabyta postać TTP występuje zdecydowanie częściej niż wrodzona. W postaci tej niedobór ADAMTS13 wynika z obecności autoprzeciwciał skierowanych przeciwko temu enzymowi (przeciwciała anty-ADAMTS13). W klasyfikacji TTP wyróżnia się postaci nabyte związane z infekcjami (np. HIV, HCV, HBV), nowotworami złośliwymi, lekami, ciążą i okresem okołoporodowym, jakkolwiek czynnik odpowiedzialny za powstawanie autoprzeciwciał nie zawsze jest możliwy do zidentyfikowania. Wszystkie te potencjalne przyczyny rozwoju TTP zostały u prezentowanej chorej wykluczone. W piśmiennictwie światowym dostępne są dane, według których w grupie chorych na niektóre schorzenia układowe (głównie toczeń i twardzina układowa) stwierdzano znamienne, w stosunku do grupy kontrolnej, obniżenie aktywności metaloproteinazy ADAMTS13. W tej grupie chorych jednak nie stwierdzono obecności autoprzeciwciał anty-ADAMTS13 oraz incydentów zakrzepowych charakterystycznych dla TTP [16]. Ten fakt może sugerować wpływ innych autoprzeciwciał na aktywność ADAMTS13, nie wyjaśnia jednak dostatecznie, czy incydenty TTP mogą być indukowane aktywnością choroby układowej tkanki łącznej [17]. Typowe objawy kliniczne oraz obecność przeciwciał anty-ADAMTS13 wskazują, iż obniżenie aktywności metaloproteinazy ADAMTS13 u omawianej chorej nie wynikało jedynie z aktywności choroby układowej tkanki łącznej.

Objawy kliniczne zakrzepowej plamicy małopłytkowej i SLE mogą być podobne, co przyczynia się do trudności diagnostycznych, a co za tym idzie - również terapeutycznych. Gorączka oraz incydenty zakrzepowo-zatorowe mogą występować w obu jednostkach chorobowych, mają jednak różne mechanizmy. W toczniu często związane jest to $\mathrm{z}$ aktywacją procesów zapalnych i/lub obecnością przeciwciał antyfosfolipidowych [18]. Podobnie niedokrwistość hemolityczna i małopłytkowość, które należą zarówno do obrazu klinicznego SLE, jak i TTP. W TTP niedokrwistość hemolityczna ma charakter mikroangiopatyczny (w rozmazie mikroskopowym obserwuje się schistocyty, a bezpośredni test antyglobulinowy BTA zwykle jest ujemny), natomiast w SLE niedokrwistość hemolityczna najczęściej ma charakter autoimmunohemolityczny (bez obecności schistocytów, BTA zwykle dodatni). Warto jednak zwrócić uwagę, iż w nefropatii toczniowej może również występować mikroangiopatyczna niedokrwistość hemolityczna. Jednym z kryteriów SLICC jest dodatni wynik bezpośredniego testu antyglobulinowego, ale tylko w przypadku braku cech niedokrwistości hemolitycznej. W przypadku prezentowanej pacjentki pomocne, chociaż z pewnością nie rozstrzygające, byłoby wyjściowe oznaczenie BTA.

Małopłytkowość w SLE jest zwykle łagodna, związana najczęściej z występowaniem przeciwciał przeciwpłytkowych lub innych przeciwciał powodujących lizę płytek [19]. Małopłytkowość w TTP, jak już wspomniano, wynika ze zużycia płytek po związaniu ich w agregaty oraz tworzenia mikrozakrzepów w naczyniach krwionośnych. Jest to zazwyczaj małopłytkowość znacznie nasilona - stężenie płytek wynosi poniżej 50 G/L. W przypadku współwystępowania obu jednostek 
chorobowych istniejącej małopłytkowości nie można uznać za kryterium tocznia (TTP stanowi kryterium wykluczające wg kryteriów SLICC).

Kolejną wspólną manifestacją kliniczną obu omawianych jednostek chorobowych są objawy neurologiczne. W oparciu o kryteria SLICC uznaje się, iż manifestacją tocznia są drgawki, psychoza, mononeuritis multiplex, zapalenie rdzenia kręgowego, neuropatia nerwów czaszkowych lub obwodowych, ostry zespół splątania, podczas gdy w TTP najczęściej występują splątanie, bóle głowy, porażenie/niedowład, afazja, dyzartia, zaburzenia widzenia, encefalopatia, śpiączka, przy czym manifestacja objawów neurologicznych może być w zasadzie dowolna. Objawy prezentowane przez opisywaną chorą rozwinęły się bardzo gwałtownie w trakcie hospitalizacji i towarzyszyły innym objawom aktywnego TTP. Bóle głowy, jakie występowały u pacjentki od okresu dzieciństwa, jakkolwiek częste, nie należą do kryteriów SLICC rozpoznania SLE.

Uszkodzenie nerek jest również charakterystyczne dla obu schorzeń. Za nefropatią toczniową przemawiać będzie stosunek stężenia białka do kreatyniny w moczu wynoszący powyżej 0,5, obecność białkomoczu dobowego powyżej 0,5 g lub stwierdzenie wałeczków czerwonokrwinkowych w osadzie moczu. W przypadku TTP praktycznie każde uszkodzenie nerek można uznać za kryterium zajęcia nerek (białkomocz i krwinkomocz często jest obecny). Brak wyników badania ogólnego moczu w okresie przed ujawnieniem się objawów TTP uniemożliwia ustalenie pochodzenia zmian w nerkach u omawianej chorej. Wyjaśnieniem mogłoby być badanie histopatologiczne bioptatu nerki, natomiast $\mathrm{z}$ uwagi na na gwałtowną manifestację kliniczną badanie to nie zostało wykonane. Ze względu na powyższe wątpliwości białkomocz jako wyraz zajęcia nerek nie został zaliczony jako kryterium rozpoznania SLE.

Przedstawione dane wyraźnie wskazują, iż współwystępowanie TTP i SLE może mieć cechy zespołu nakładania [20]. Rozpoznanie każdej z tych chorób opiera się na spełnieniu odpowiednich kryteriów klasyfikacyjnych. W prezentowanym przypadku rozpoznanie SLE ustalono w oparciu o kryteria SLICC, w których wymagane jest spełnienie minimum 4 kryteriów z 11 klinicznych i 6 serologicznych. Za kryteria SLE uznano zmiany skórne plamisto-grudkowe, obecność ANA, anty-dsDNA, limfopenię, wypadanie włosów. Pozostałe objawy, jak anemia hemolityczna, białkomocz i małopłytkowość, mogły w tym przypadku wynikać zarówno z SLE, jak i TTP, więc nie brano ich pod uwagę jako kryteriów klasyfikacyjnych tocznia. Obecność przeciwciał anty-dsDNA, pomimo iż krytykowana jako samodzielne kryterium rozpoznania SLE, jest umieszczone w kryteriach SLICC. Były one oznaczone przed rozpoczęciem leczenia i występowały w znaczącym stężeniu. Nie stwierdzano również współistniejącej infekcji, która mogłaby być odpowiedzialna za wynik fałszywie dodatni.

Z punktu widzenia praktyki klinicznej najważniejszym celem diagnostyki różnicowej jest ustalenie szybkiego rozpoznania zakrzepowej plamicy małopłytkowej i w miarę możliwości czynnika wywołującego lub schorzenia współistniejącego. Każda małopłytkowość i niedokrwistość hemolityczna o niejasnej przyczynie powinna budzić podejrzenie TTP. W potwierdzeniu rozpoznania bardzo pomocny jest rozmaz mikroskopowy krwi z oceną występowania schistocy tów, czyli rozfragmentowanych erytrocytów, które w prawidłowych warunkach obecne są we krwi w niewielkim odsetku (do 1). Ich obecność potwierdza mikroangiopatyczną przyczynę niedokrwistości. Metodą z wyboru w leczeniu TTP jest wymiana osocza (plazmafereza), polegająca na zastąpieniu osocza pacjenta osoczem świeżo mrożonym. Celem takiego postępowania jest zmniejszenie ilości patogennych przeciwciał blokujących proteazę ADAMTS13, usunięcie nadmiaru multimetrów vWF oraz dostarczenie obecnej w osoczu dawców aktywnej ADAMTS13. Ze względu na charakter tego zabiegu ważne jest, aby przed jego rozpoczęciem zabezpieczyć próbki krwi do dalszych oznaczeń, m.in. aktywności ADAMTS13 oraz autoprzeciwciał przeciwko temu enzymowi, czynników infekcyjnych, ciąży, chorób układowych, w tym tocznia oraz zespołu antyfosfolipidowego. Zabiegi plazmaferezy są leczeniem o udokumentowanej skuteczności - obniżają śmiertelność z 90\% do ok. 10\%. Zaleca się codzienną wymianę 3-4 L osocza do czasu osiągnięcia remisji. Jeżeli zabiegu nie można przeprowadzić, zaleca się przetoczenie świeżo mrożonego osocza, jednak postępowanie takie wiąże się ze znamiennie większą śmiertelnością, mniejszym odsetkiem remisji oraz większym ryzykiem powikłań. Jednocześnie stosuje się glukokortykosteroidy. Inne leki immunosupresyjne, w tym rituksimab [21], cyklosporyna lub cyklofosfamid, są stosowane w przypadkach opornych na plazmaferezę i sterydoterapię [5]. W przyszłości zastosowanie w leczeniu zakrzepowej plamicy małopłytkowej może znaleźć rekombinowany ludzki enzym ADAMTS13, na co wskazują dotychczasowe wyniki badań na zwierzętach [22]. Oczywistym jest, iż w przypadku współwystępowania tocznia układowego, zwłaszcza przy podejrzeniu zajęcia nerek, wskazane jest zastosowanie leczenia immunosupresyjnego. Schemat leczenia uzależniony jest od klasy nefropatii toczniowej [23]. W klasie III i IV nefropatii toczniowej zalecane jest stosowanie cyklofosfamidu w 2 schematach: 6 cykli cyklofosfamidu niskodawkowanego (6 × po $500 \mathrm{mg}$ ) co 2 tygodnie z następczą terapią mykofenolanem mofetilu (MMF) 1-2 g na dobę po uzyskaniu poprawy lub schemat wysokodawkowy uwzględniający 6 podań po 1,0 g cyklofosfamidu i.v, i następnie przejście na MMF. W prezentowanym przypadku zastosowano niestandardowe leczenie cyklofosfamidem - podano 3 g leku i wobec bardzo dobrej poprawy klinicznej w 29-letniej chorej planującej posiadanie potomstwa, zdecydowano o przejściu na leczenie podtrzymujące MMF.

\section{PODSUMOWANIE}

Współwystępowanie tocznia rumieniowatego układowego oraz zakrzepowej plamicy małopłytkowej ma znamiona zespołu nakładania i może sprawiać trudności diagnostyczne. Wczesne postawienie rozpoznania TTP i podjęcie niezwłocznie zalecanego leczenia jest kluczowym czynnikiem decydującym o rokowaniu. 


\section{PIŚMIENNICTWO}

1. Moschcowitz E.: Hyaline thrombosis of the terminal arterioles and capillaries: a hither to undescribed disease. Proc NY Pathol Soc. 1924, 24, 21-24.

2. Furlan M., Robles R., Lammle B.: Partial purification and characterization of a protease from human plasma cleaving von Willebrand factor to fragments produced by in vivo proteolysis. Blood. 1996, 87 (10), 4223-4234.

3. Kremer Hovinga J.A., Studt J.D., Alberio L., Lammle B.: Von Willebrand factor cleaving protease (ADAMTS-13) activity determination in the diagnosis of thrombotic microangiopathies: the Swiss experience. Semin Hematol. 2004, 41 (1), 75-82.

4. Ruggenenti P., Remuzzi G.: The pathophysiology and management of thrombotic thrombocytopenic purpura. Eur J Haematol. 1996, 56 (4), 191-207.

5. Scully M., Hunt B.J., Benjamin S., Liesner R., Rose P., Peyvandi F. et al.: Guidelines on the diagnosis and management of thrombotic thrombocytopenic purpura and other thrombotic microangiopathies. Br J Haematol. 2012 158 (3), 323-335.

6. Petri M., Orbai A.M., Alarcon G.S., Gordon C., Merrill J.T., Fortin P.R. et al.: Derivation and validation of the Systemic Lupus International Collaborating Clinics classification criteria for systemic lupus erythematosus. Arthritis Rheum. 2012, 64 (8), 2677-2686.

7. Hamasaki K., Mimura T., Kanda H., Kubo K., Setoguchu K., Satoh T. et al.: Systemic lupus erythematosus and thrombotic thrombocytopenic purpura: a case report and literature review. Clin Rheumatol. 2003, 22 (4-5), 355-358.

8. George P., Das J., Pawar B., Kakkar N.: Thrombotic thrombocytopenic purpura and systemic Lupus erythematosus: Successful management of a rare presentation. Indian J Crit Care Med. 2008, 12 (3), 128-131.

9. Kwok S.K., Ju J.H., Cho C.S., Kim H.Y., Park S.H.: Thrombotic thrombocytopenic purpura in systemic lupus erythematosus: risk factors and clinical outcome: a single centre study. Lupus. 2009, 18 (1), 16-21.

10. Ali Taha A.H., Elbadry M.I., Tawfik M.A.: A case report of thrombotic thrombocytopenic purpura associated with systemic lupus erythematosus: overlapping features. Am J Med Case Rep. 2014, 10 (2), 206-213.
11. Coppo P., Veyradier A.: Thrombotic microangiopathies: towards a pathophysiology-based classification. Cardiovasc Hematol Disord Drug Targets. 2009, 9 (1), 36-50.

12. Mok C.C., Lau C.S.: Pathogenesis of systemic lupus erythematosus. J Clin Pathol. 2003, 56 (7), 481-490.

13. Bellone M.: Autoimmune Disease: Pathogenesis. In: Encyclopedia of life sciences. John Wiley \& Sons, New York 2010

14. Hahn B.H.: Antibodies to DNA. N Engl J Med. 1998, 338 (19), 1359-1368.

15. Cheung W.Y.: Thrombotic thrombocytopenic purpura and systemic lupus erythematosus - distinct entities or overlapping syndromes? Transfus Apher Sci. 2006, 34 (4), 263-266.

16. Mannucci P.M., Vanoli M., Forza I., Canciani M.T., Scorza R.: Von Willebrand factor cleaving protease (ADAMTS-13) in 123 patients with connective tissue diseases (systemic lupus erythematosus and systemic sclerosis). Haematologica. 2003, 88 (8), 914-918.

17. Shah A.A., Higgins J.P., Chakravarty E.F.: Thrombotic microangiopathic hemolytic anemia in a patient with SLE: diagnostic difficulties. Nat Clin Pract Rheumatol. 2007, 3 (6), 357-362.

18. Al-Homood I.A.: Thrombosis in systemic lupus erythematosus: a review article. ISRN Rheumatol. 2012, Article ID 428269.

19. Hrycaj P., Cieślak D.: Zajęcie układu krwiotwórczego w przebiegu tocznia rumieniowatego układowego. Reumatologia. 2013, 51 (1), 31-35.

20. George J.N., Vesely S.K., James J.A.: Overlapping features of thrombotic thrombocytopenic purpura and systemic lupus erythematosus. South Med J. 2007, 100 (5), 512-514.

21. Scully M., McDonald V., Cavenagh J., Hunt B.J., Longair I., Cohen H. et al.: A phase 2 study of the safety and efficacy of rituximab with plasma exchange in acute acquired thrombotic thrombocytopenic purpura. Blood. 2011, 118 (7), 1746-1753.

22. Schiviz A., Wuersch K., Piskernik C., Dietrich B., Hoellriegl W., Rottensteiner H. et al.: A new mouse model mimicking thrombotic thrombocytopenic purpura: correction of symptoms by recombinant human ADAMTS13. Blood. 2012, 119 (25), 6128-6135.

23. Zdrojewski Z: Nowoczesne metody diagnostyczne i terapeutyczne nefropatii toczniowej. Ann Acad Med Stetin. 2011, 57, 3, 39-48. 